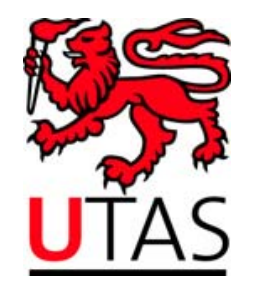

SCHOOL OF ECONOMICS AND FINANCE

Discussion Paper 2012-05

Liquidity and Crude Oil Prices:

China's Influence Over 1996-2011

Ronald A. Rattia and Joaquin L. Vespignani

ISSN 1443-8593

ISBN 978-1-86295-673-5 


\title{
Liquidity and Crude Oil Prices: China's Influence Over 1996-2011 ${ }^{\Delta}$
}

\author{
Ronald A. Ratti ${ }^{\mathrm{a}^{*}}$ and Joaquin L. Vespignani ${ }^{\mathrm{b}^{* *}}$ \\ ${ }^{a}$ University of Western Sydney, School of Business, Australia \\ ${ }^{\mathrm{b}}$ University of Tasmania, School of Economics and Finance, Australia
}

\begin{abstract}
Movement in China's money supply drives the movement in world money supply over the last twenty years. Within the framework advanced by Kilian (2009) that identifies the supply and demand side factors driving oil price changes we introduce the influence of liquidity in China and other countries on oil price changes. Structural shocks are large for both G3 (U.S., Eurozone and Japan) real M2 and China's real M2. However, the cumulative impact of real G3 M2 shocks on real oil prices is small in contrast to a large cumulative effect of China's real M2 on the real price of crude oil. It is shown that increased liquidity in China relative to that in the U.S., Eurozone and Japan significantly raises real oil prices over 1996:1-2011:12. Following a sharp fall in real oil price in the last half of 2008, the cumulative impact of China's real M2 on the real price of crude oil is particularly substantial in the recovery of oil price during 2009 from a low of $\$ 41.68$ for January 2009. The analysis sheds light on the causes of movement in oil prices over the last twenty five years and in assessing the relative importance of China in the upsurge of the real price of crude oil.
\end{abstract}

Keywords: Oil Price, China’s Global Influence, Oil Price and Liquidity

JEL Codes: E31, E32, Q43

\footnotetext{
** Corresponding author: Joaquin L. Vespignani; University of Tasmania, School of Economics and Finance, Australia; Tel. No: +61 3 62262825; E-mail address: Joaquin.Vespignani@utas.edu.au

* Ronald A. Ratti; University of Western Sydney, School of Business, Australia; Tel. No: +61 29685 9346; E-mail address: r.ratti@uws.edu.au
}

\footnotetext{
${ }^{\Delta}$ The authors thank Lutz Kilian and Mardi Dungey for helpful suggestions on improving the paper.
} 


\section{Liquidity and Crude Oil Prices: China’s Influence Over 1996-2011}

\section{Introduction}

Hamilton (2011) identifies 1997-2010 as a "new industrial age" characterized by billions of people making the transition from agricultural to industrial activity and with increases in real income beyond subsistence levels. The newly industrialized economies have absorbed over two-thirds of the increase in world oil consumption since 1998. Hamilton (2011) notes that China has a $6.3 \%$ compound annual growth rate for petroleum consumption since 1998 and that oil demand from emerging market countries is the most important factor influencing oil prices in recent years and is likely to remain so in future decades. ${ }^{1}$ Kilian and Hicks (2012) associate the movements in real oil price over 2003-2008 with unexpected growth in emerging economies (primarily China and India). Real oil price increases are connected with surprisingly strong growth forecasts in emerging economies and the decline in real oil prices after mid 2008 are predicted by the forecasts of decline in global growth.

In the literature there has been discussion about whether oil prices were exogenous to global macroeconomic conditions. Bernanke, Gertler and Watson (1997) argue that 1970s and 1980s were marked by exogenous oil price shocks the effects of which were then disseminated by the reaction of monetary policy makers resulting in stagflation. ${ }^{2}$ Counter to this view Barsky and Kilian (2002) argue that change in monetary policy regimes was a key factor behind the oil price increases of the 1970s and the subsequent stagflation in many major economies. Barsky and Kilian (2002) note that in the 1970s there were large swings in global liquidity measured by money growth in ten industrial economies (the United States and other OECD countries). Barsky and Kilian (2002) show that the

\footnotetext{
${ }^{1}$ Hamilton (2011) provides a review of the oil industry and analyses events influencing oil price. Hamilton (2009) shows that the oil price increases during 2007 and 2008, due to strong global demand for oil, had the effect of significantly reducing consumption spending and purchases of automobiles in the U.S. He argues that these effects of the oil price increases tipped the U.S. into recession during 2007:Q4 to 2008:Q3.

${ }^{2}$ Kilian and Vigfusson (2011) prove that the BGW analysis was invalid because they used inconsistent estimators. Kilian and Lewis (2011) show that the BGW results no longer hold when these problems are fixed. For an authoritative review of the exogeneity issue see Kilian (2008b). The view that oil price shocks are exogenous appears in the seminal paper by Hamilton (1983).
} 
substantial increase in industrial commodity prices that preceded the increase in oil prices in 19731974 is consistent with the view that rising demand based on increased global liquidity drove oil prices higher.

Frankel (2008) examines the links between monetary policy and the prices of agricultural and mineral commodities. Barsky and Kilian (2002) and Frankel (2008) argue that easy monetary policy indicated by low real interest rates might lead to high real commodity prices. Frankel and Rose (2010), among others, have subsequently shown that there is no empirical support for this conjecture. Frankel and Rose (2010) emphasize that the price of oil is determined by supply of and demand for stocks and supply and flow demand for flows. The idea regarding oil stocks goes back to early versions of Alquist and Kilian (2010) who present and test a formal model. Kilian and Murphy (2010) analyze this question empirically in a serious way and rule out speculative trading as an explanation for the 2003-08 oil price surge. Belke, Bordon and Hendricks (2010) find that causality between monetary aggregates and oil prices run both ways. Bodenstein, Guerrieri and Kilian (2012) develop and evaluate a fully specified DSGE model with monetary policy shocks and systematic monetary policy responses. They show that causality in the relationship between monetary policy and oil prices, run from the event of oil market to monetary policy as well as of shifts in monetary policy to the supply of oil and demand of oil in global markets.

Within the framework advanced by Kilian (2009) that identifies the supply and demand side factors driving oil price changes we introduce the influence of liquidity in China and in other major countries on oil price changes. It is shown that movement in China's money supply drives the movement in world money supply over the last twenty years. China's money supply is significantly associated with real increases in the price of oil, whereas U.S., Eurozone, and Japanese money supplies are not. It is shown that increased liquidity in China relative to that in the U.S., Europe and Japan significantly raises real oil prices over 1996:1-2011:12. Following a sharp fall in the last half of 2008, real oil price rose strongly over 2009-2010. This rise was mostly due to strong effects of 
shocks from China's real M2 (especially during 2009) and global real aggregate demand shocks (especially during 2010).

In response to an unanticipated increase in China's real M2 growth there are significant increases in real oil prices that build up over six months and then persist. In contrast, innovations to U.S., Japanese or Eurozone real M2 do not significantly affect real oil price. Structural shocks are large for both G3 real M2 and China's real M2. However, the cumulative impact of real G3 M2 shocks on real oil prices is small in contrast to a large cumulative effect of China's real M2 on the real price of crude oil. Over 1996:1-2011:12 a positive global real activity shock has an effect on real oil prices that builds up for several months and is significant over the first six months, after which the effect gradually erodes. An unanticipated negative innovation in global oil production causes the real price of oil to increase slightly for several months but the effect is transitory and does not persist. An increase in precautionary demand for crude oil causes significant and sustained increases in real oil prices.

The behaviour of China's M2 and that of other major countries is examined in Section 2. The structural vector autoregressive model for analysis of real crude oil prices is discussed in Section 3. The empirical results are presented in Section 4. Section 5 concludes.

\section{China M2 and Global M2}

The growing importance of China's money supply for global liquidity is illustrated in Figure 1. In Figure 1a the log of M2 money supplies in China, U.S., Eurozone, Japan, the U.K. and Switzerland over 1996:01-2011:12 are presented. In Figure 1b the log of global M2 is shown. Global M2 is taken to be the sum of the M2 in China and in the G3. Throughout the paper we take the G3 to be the U.S., Eurozone and Japan. The rise of China's money supply as share of global money supply has been marked. In 1996 China's M2 measured in U.S. dollars only account for less than 5\% of global M2, however by 2011 this share increased to $28 \%$. In terms of growth rate, China's M2 
measure in USD account for 75\% of the increase in global M2 registered between 1996 and 2011. For this reason, the upward trend in global M2 in Figure 1b is due to the behaviour of China's M2. Chinese M2 growth rate has driven global M2 growth since at least 2000. The behaviour of China's nominal GDP is similar to that of China's nominal M2 and is strongly upward. This pattern is illustrated in Figure 1c. From 1996 to 2011 China's nominal GDP (in USD) increased on average by $15 \%$ per year and M2 (in USD) increased on average by $19.5 \%$ per year.

The nominal oil price and G3 M2 and China M2 are shown in Figure 1d. In Figure 1d China's M2 is strongly upward and the G3 M2 is much flatter. Nominal China's M2 trends much closer to oil prices than the G3 M2. Given these facts and the argument made by Bodenstein, Guerrieri and Kilian (2012; page 51) “... there is consensus that causality in this relationship (referring to monetary policy and oil prices) run from the event of oil market to monetary policy as well of shifts of monetary policy to the supply of oil and demand of oil in global markets", we believe that a credible hypothesis is the argument that China's expansive money supply is in part responsible for higher oil prices. The sizeable nature of China's M2 expansion relative to that of the G3 is also apparent in real terms. In Figure 1e, China's real M2 has a much stronger upward trend than the G3's real M2 (the deflator is the U.S. PPI index for commodities). Based on an index of 100 in 1996, by 2011:12 China's real M2 index is 340 and the G3's real M2 index is 150.

\section{Methodology}

A major contribution of Kilian (2009) is the decomposition of the structural shocks influencing the movement of real oil price and an examination of how these structural shocks evolve over time. Kilian (2009) proposed a decomposition of the real price of crude oil into oil supply shocks, aggregate shocks to world demand for industrial commodities and a residual. The latter is associated with precautionary demand shocks specific to the crude oil market due to worries about future oil supplies. 
In this paper we build on the Kilian (2009) model by introducing liquidity into the model. If liquidity is only a veil over real values, then real M2 in the G3 and in China will not significantly influence the real price of oil. The structural VAR model (SVAR) is expressed in matrix form as (for simplicity the constant term is omitted):

$$
B_{0} X_{t}=\sum_{i=1}^{j} B_{i} X_{t-i}+\varepsilon_{t}
$$

where $j$ is the optimal lag length, determined by the Akaike Information Criterion (AIC) and Bayesian Information Criterion (BIC), $X_{t}$ is vector of endogenous variables, and $\varepsilon_{t}$ is the vector of structural changes, which is serially and mutually independent.

Liquidity is introduced into the model in the form of real M2 for the G3 and real M2 for China. The endogenous variables in the model are:

$$
X_{t}=\left[G O_{t}, A D_{t}, R P_{t}, G 3 M 2_{t}, C M 2_{t}\right]
$$

where $G O_{t}$ is percentage change in global oil production, $A D_{t}$ is global real aggregate demand (from Kilian (2009)), $R P_{t}$ is percentage change in the real price of oil, the nominal price of oil (WTI) deflated by the U.S. PPI for commodities, G3M2 is percentage change in G3 M2 in U.S. dollars deflated by the PPI, and CM $2_{t}$ is percentage change in China's M2 in U.S. dollars deflated by the U.S. producer price index for all commodities (PPI). We feel that deflation by the PPI is appropriate since it used to adjust nominal values to obtain real output and the measure of real global aggregate demand, $A D_{t}$, is based on changes in the demand for all industrial commodities (as reflected in shipping prices), and because we are considering global liquidity and the PPI is reflective of global influences. Kilian (2009) deflates nominal oil price by the U.S. CPI. In robustness tests we find that use of the U.S. CPI as deflator for oil price, G3 M2 and China's M2 yield the same (maybe somewhat better) qualitative results as using the PPI as deflator for these nominal variables.

To identify the model restriction are imposed in the $B_{o} X_{t}$ as follows: 


$$
B_{O} X_{t}=\left[\begin{array}{ccccc}
1 & 0 & 0 & 0 & 0 \\
-b_{20} & 1 & 0 & 0 & 0 \\
-b_{30} & -b_{31} & 1 & 0 & 0 \\
-b_{40} & -b_{41} & -b_{42} & 1 & 0 \\
-b_{50} & -b_{51} & -b_{52} & -b_{53} & 1
\end{array}\right]\left[\begin{array}{c}
\beta_{10, t}^{G O \text { shock }} \\
\beta_{20, t}^{A D} \text { shock } \\
\beta_{30, t}^{R P \text { shock }} \\
\beta_{40, t}^{G 3 M 2 \text { shock }} \\
\beta_{50, t}^{C M 2 \text { shock }}
\end{array}\right]
$$

Model restrictions are based on those in Kilian (2009), to the extent possible, given the inclusion in our model of the monetary variables. Restrictions are only imposed in the contemporaneous matrix. These restrictions are placed using Cholesky decomposition lower triangle matrix shown in equation (3) and are motivated as follows. ${ }^{3}$ Shocks to oil production are assumed to not respond to the other structural shocks. Oil production only depends on lags of the other variables since it will take some time for oil producer to alter production in response to the other shocks. Oil production is unlikely to respond to the other shocks within the same month.

The global real economic activity indicator responds contemporaneously to oil production shocks, because the world demand for industrial commodities could be affected immediately by, for example, an oil production shortage. However, this indicator is expected to responds with some delay to monetary variables and oil prices. The global aggregate demand for industrial commodities will not respond to money supply shocks in the same month. Innovations to the real price of oil not explained by shocks to oil supply or real aggregate demand will reflect changes in the sector specific demand for oil as opposed to changes in the demand for all industrial commodities.

The identifying restrictions in the system (3) imply that shocks to global oil production and global real aggregate demand, and real oil price will influence real M2 in the G3 and in China, and not the reverse. In system (3), shocks to real money supply in the G3 and in China will not influence oil supply, real aggregate demand and the real price of oil in the same month. We assume that China's M2 depends contemporaneously on G3 M2. China's M2 is substantially smaller than G3 M2 over most of the sample and China's lenders and monetary authorities are more likely to see (at least in partial data release) contemporaneously global monetary movements (than the opposite).

\footnotetext{
${ }^{3}$ For more detail about the Cholesky decomposition see Hamilton (1994; page 87).
} 
The Akaike Information Criterion (AIC) and the Bayesian information Criterion (BIC) are used for selection of for optimal lag length. We choose the most parsimonious specification for reasons of efficiency. ${ }^{4}$ The AIC selected three lags and the BIC selected two lags. Results are not affected by a longer lag selection. To test for autocorrelation and heteroskedasticity, the residual serial correlation LM test and the VAR residual heteroskedasticity test are carried out. The null hypothesis of both, no serial correlation and no heteroskedasticity of the joint combinations of all error term products cannot be rejected at the 5\% level (respectively).Consequently, the present of either autocorrelation and/or heteroskedasticity are discarded. An important condition to be satisfied in any VAR model is that the lag structure included also has to be stationary. The inverse roots of AR characteristic polynomial test shows that no root lies outside the unit circle, suggesting that our models have stable roots.

\section{Data and variables}

Data are monthly data from February 1996 to December 2011 since the M2 series for China is only available from January 1996. This starting date also coincides with Hamilton's (2011) structural break analysis. Real oil price is the change in the log of the spot price of Western Texas Intermediate (WTI) oil divided by the U.S. producer price index for all commodities (PPI). ${ }^{5}$ Following Kilian (2009), global oil production is an endogenous variable. ${ }^{6}$ The spot price of WTI and global oil production are obtained from the U.S. Department of Energy. Global demand for real economic activity is given by Kilian's (2009) global index of dry cargo single voyage freight rates.

\footnotetext{
${ }^{4}$ In the literature on oil price shocks selection of a shorter lag for efficiency is quite common. For example, see Park and Ratti (2008) and Sadorsky (2012).

${ }^{5}$ In the literature on oil price shocks most of the analysis is in terms of real oil price effects. If the nominal price of oil is free to adjust to inflation pressures, inflation innovations would be immediately reflected in the nominal price of oil. Gillman and Nakov (2009) and Alquist, Kilian and Vigfusson (2010) note that in the absence of regulation, a positive U.S. monetary disturbance would be expected to raise the nominal dollar price of oil and U.S. consumer prices to the same extent, leaving the real price of oil unaffected. In this paper we will examine the effect of global liquidity on the real price of oil.

${ }^{6}$ Global oil production may with time respond to the other variables in the VAR as well as to geopolitical events. For example, Kilian (2008a) and Hamilton (2009) identify unrest in Venezuela over December 2002 and January 2003 and the second Persian Gulf War over February and March 2003 as disruptive for oil production.
} 
Advantages of this measure are that it is available at a monthly frequency in contrast to real GDP which is only available quarterly and it reflects global demand for commodities rather demand within one particular country. ${ }^{7}$ A monthly interpolated version of global GDP is also used in our robustness analysis.

G3 M2 is constructed by aggregating M2 in USD for the 3 largest economies, the United States, the Eurozone and Japan. M2 in each of the G3 is far larger than M2 in any other country over 1996-2011 with the exception of China in recent years. China's M2 is in USD. Use of M2 as measure of liquidity is based on the following observations. First, M2 is the only measure of China's money supply going back to 1996. Second, M2 is reported in domestic currency and upon conversion to USD is easily aggregated into a global liquidity indicator (without raising issues about appropriate weights over time that arise in constructing a global liquidity indicator based on interest rates). M2 is deflated by the U.S. PPI for commodities. Growth rates in G3 real M2 and China's real M2 appear in the model. Data on M2 are obtained from International Financial Statistics (IMF).

The assumption of the VAR model requires that all variables in the model must be stationary, or that the linear combinations of non-stationary but co-integrated variables must be stationary. The Augmented Dickey Fuller (ADF) unit root test reveals that the logarithm of oil production, G3 M2, Chinese M2 and oil prices are only first difference stationary. The p-values for the null hypothesis of having a unit root are: $0.44,0.98,0.99$ and 0.77 respectively. The Phillip-Perron (PP) and the Kwiatkowski-Phillips-Schmidt-Shin (KPSS) tests also suggest use of log first differences. The null hypothesis of unit root in the real price of oil cannot be rejected at $76 \%$ for monthly data over 1996:01-2011:12. Kilian's (2009) indicator of global activity is an index already constructed to be stationary. (It is a business cycle index). Consequently, we take log first differences of the variables oil production, G3M2, CM2 and oil prices to avoid spurious regression results.

\footnotetext{
${ }^{7}$ Monthly global industrial production can be constructed from International Financial Statistics (IMF). However, the aggregation of industrial production and the lack of clarity about how this index is constructed make it quite controversial as discussed by Kilian (2009).
} 


\section{Results}

\subsection{The structural shocks}

Figure 2 shows the behaviour of the structural shocks to global oil production, global real aggregate demand, G3 real M2, China's real M2 and oil-specific demand, recovered from estimating the SVAR in equation (3). The structural shocks are expressed as annual averages. The structural shocks change over time. An interesting feature of figure 2 is that global oil supply and aggregated demand shocks in the period 1996-2011 are relatively small compared the other shocks. Monetary shocks and precautionary shocks are large during this period consistent with the unprecedented global monetary expansion observed mainly in China but also observed in Japan and EU. It is interesting that both the G3 real M2 and China real M2 structural shocks are substantial over the last twenty-five years.

The rapid increase in oil price leading to a peak in June 2008 is associated with positive global real aggregate demand, low spare production capacity and oil specific precautionary demand. ${ }^{8}$ Up to June 2008 structural shocks to G3 real M2 are large and structural shocks to China's real M2 are positive, but not as large. The fall in oil price from July 2008 to February 2009 is associated with the global financial crisis during late 2008, recession in the U.S. over December 2007 to June 2009, and weak growth in Europe. This is reflected in Figure 2 in that the structural shocks global real aggregate demand, G3 real M2 and oil specific precautionary demand are negative at the end of 2008. OPEC decreases production target from September 2008 to January

The rise in oil price from January 2009 through April 2011 is associated with large positive structural shocks to G3 real M2 and China's real M2 up through early 2010, positive shocks to global real aggregate demand and oil specific precautionary demand starting at the end of 2009 up through much of 2010, and global supply shock through late and early 2011. External events at this time (2009-2011) include weak recovery from recession in West and strong demand for oil in Asia.

\footnotetext{
${ }^{8}$ In the monthly data, spot prices per barrel for WTI are \$58.14 in January 2007 and $\$ 140$ in June 2008. Spot price for WTI is \$41.68 in January 2009 and is \$133.93 in April 2011.
} 
During 2011 oil production is disrupted in Libya and there is political turmoil in several Middle Eastern countries.

\subsection{The impulse response effects of the structural shocks}

Figure 3 shows the responses of the variables in the SVAR to one-standard deviation structural innovations. The dashed lines represent a two standard error confidence band around the estimates of the coefficients of the impulse response functions. ${ }^{9}$ In the first column are shown the responses of global oil production, real economic activity, G3 real M2, China's real M2 and the real price of oil to a structural innovation in global oil production. A supply disruption significantly reduces the production of oil that is only partly offset in the first three months. The effect of an unanticipated supply disruption on global oil production is very persistent and highly significant. An unanticipated negative innovation in global oil production does not cause significant effects on the other variables, although the tendency is for real economic activity to fall for an extended period and the real price of oil to increase slightly for several months.

In the second column of Figure 3 a positive global real activity shock has a persistent positive effect on global oil production that builds up to a level that is statistically significant over a 4 to 6 month window before levelling off. A positive global real activity shock has a persistent effect on real oil prices that builds up for several months and is significant over the first six months, after which the effect gradually erodes. ${ }^{10}$ An unanticipated aggregate demand expansion has a very persistent and highly significant effect on global real economic activity that rises over time and only tends to level off after 20 months. A positive shock to global real activity has a significant negative

\footnotetext{
${ }^{9}$ The confidence bands are obtained using Monte Carlo integration as described by Sims (1980), where 500 draws were used from the asymptotic distribution of the VAR coefficient.

${ }^{10}$ This result is different from the finding by Kilian (2009) for 1973:1-2007:12 in that a positive shock to aggregate demand for all industrial commodities resulted in a significant oil price increase that builds up over the first year and then is sustained at a large value. The finding that aggregate demand for all industrial commodities has a lesser effect over 1996:1-2011:12 is not due to the inclusion of M2 variables in the SVAR. For a 3 variable SVAR along the lines of Kilian's (2009) model estimated over 1996:1-2011:12 results in a significant effect of a positive shock to aggregate demand for all industrial commodities on real oil price only over the first three months (after which the effect gradually erodes).
} 
effect on the G3 real M2 for a six month period and growth rate and an insignificant negative effect on China's real M2.

In the fourth (third) column are shown the responses of global oil production, global real economic activity, G3 real M2, China's real M2 and the real price of oil to a structural innovation in China's (G3) real M2. In response to an unanticipated increase in China's real M2, there are significant and persistent increases in global oil production and in real oil prices. Global real economic activity and G3 real M2 are not significantly affected by innovations to China's real M2, although the former tends to increase over an extended period and latter tends to increase for several months. In contrast to the effect of innovations in China's real M2, an unanticipated increase in G3 real M2 does not significantly affect any of the other variables. These results underline the fact that for effects on real oil prices it matters where the innovation in money is originating. Over 1996:012011:12 an innovation in China's real M2 has significant effects on real oil price whereas an innovation in real M2 in the G3 does not.

The effects of an oil market-specific demand shock are shown in column 5 of Figure 3 . A positive in oil market-specific demand shock has a large and persistent positive effect on the real price of oil. This effect is highly statistically significant and rises in magnitude over the first three months and then erodes only very slowly. Alquist and Kilian (2010) take this overshooting to be consistent with models of precautionary demand for oil in which inventories are pre-set and will not adjust completely to an increase in uncertainty immediately. An oil market-specific demand shock is not associated with significant effects on global real economic activity or global oil production.

A positive oil market-specific demand shock is linked with significant declines in G3 real M2 and China's real M2. Positive innovations global real economic activity is linked with a significant decline in G3 real M2 for about six months and a decline China's real M2. These findings of monetary contraction are consistent with those by Kilian and Lewis (2011) that in response to positive innovations in aggregate demand shock and oil market-specific demand there are significant 
and sustained increase in the federal funds rate. ${ }^{11}$ Innovations global oil production do not significantly affect G3 real M2 or China's real M2.

\subsection{Cumulative effect of structural shocks on real price of oil}

The cumulative contribution to the real price of oil of the structural shocks to global oil production, global real aggregate demand, G3 real M2, China's real M2 and oil-specific demand are reported in Figure 4 over 1996:01-2011:12. A quick look at Figure 4 indicates that the largest cumulative contributions to real oil price movement over time are structural shocks to global real aggregate demand, China's real M2 and oil market-specific demand shocks. The global oil production shocks are small in Figure 2 during this period. In Figure 4 the cumulative contribution of oil supply to real oil prices is also small during 1996:01-2011:12. Interestingly, even though the global real aggregate demand shocks are also relatively small in figure 2 , the cumulative contribution of aggregate demand shocks on the real price of crude oil are sometimes large. This maybe because most of the aggregate demand shock come from developing economies.

Monetary shocks are large for both G3 real M2 and China's real M2 in figure 2. The cumulative impact of real G3 M2 shocks on real oil prices in Figure 4 is small. In contrast, the cumulative effect of China's real M2 on the real price of crude oil is large. The cumulative impact of China's real M2 on the real price of crude oil is particularly substantial in the recovery of oil price during 2009 and early 2010 from a low of $\$ 41.68$ for January 2009. The precautionary oil-specific demand shocks are very large in Figure 2 and the cumulative impact of oil-specific demand shocks on the real oil prices are very large in Figure 4. Oil-specific demand shocks played a role in the rise in oil price up to mid-2008 and in the fall in oil price up until January 2009. With oil price rising strongly during most of 2009, the effect of oil-specific demand shocks working to lower real oil price

\footnotetext{
${ }^{11}$ Kilian and Lewis (2011) obtain these findings by adding the federal funds rate as a fourth variable to a Kilian (2009) SVAR model for the sample period is 1973.2-2008.6. Kilian and Lewis (2011) find that in response to oil supply disruption is a reduction in the federal funds rate. Fan et al. (2011) observe that the central bank of China maintains that the money supply is the main monetary tool in China, a view confirmed by the analysis in their paper.
} 
were overwhelmed by strong effects boosting oil price from China's real M2 and global real aggregate demand shocks.

\subsection{Robustness checks}

Several checks of the robustness of the finding that China's M2 strongly influences oil price whereas shocks to the G3 countries' M2 do not will now be conducted. Results for the last half of the sample will be examined. Results will be examined when the U.S. CPI is used to deflate all nominal values rather than the PPI. Results when global interpolated real GDP is substituted for (Kilian's (2009)) global real aggregate demand for commodities will also be examined.

Examination of the behaviour of China's M2 in Figure 1 suggests that there have been considerable changes relative to the values of the other variables in the analysis over 1996 to 2011. As recently as 2004, China's M2 was only $41.2 \%$ of that for the Eurozone, Japan or the U.S. Currently China's M2 exceeds that in all other countries including the Eurozone. A desirable property of an econometric model is that results should reflect similar results when a subsample from the original sample is used. In particular, in this analysis we are interested in testing whether or not our general results hold for a more contemporaneous subsample. Figure 5 shows the responses of the variables in the SVAR to one-standard deviation structural innovations using a subsample from 2004:02 to 2011:12 (the second half of the original sample). ${ }^{12}$ The results in Figure 5 are similar to those in Figure 3 for the full sample. These figures show that the difference between the responses of oil prices to G3 M2 and China M2 shocks are relatively larger over 2004:02 to 2011:12 than over the whole period. In Figure 5, a one standard deviation shock in China's M2 yields a response in real oil price of over $4.6 \%$ after six months. Over the whole sample, shocks to China's M2 yields smaller (but also significant) effects on the real price of oil. The reason for this magnified effect over 2004:02 to 2011:12 is probably that China's M2 has become larger relative to G3 M2.

\footnotetext{
${ }^{12}$ Others more contemporaneous subsamples such as the subsample from July 2007 to December 2011, have also been estimated showing that the main results hold.
} 
Figure 6 shows the responses of the variables in the SVAR to one-standard deviation structural innovations when all nominal variables, China's M2, the G3 M2 and nominal oil price, are deflated by the U.S. CPI rather than the PPI. Results with CPI as deflator are similar to those reported with use of the PPI. In particular, the impulse response on oil price of one standard deviation shock to G3 M2 is not statistically significant whereas the impulse response on oil price of one standard deviation shock to China's M2 is statistically significant and persistent (in the third row of the fourth and fifth columns, respectively). Global oil production does (not) respond significantly and for an extended period to a shock to China's (G3) M2 in the first row of the fifth (fourth) column in Figure 6.

An attractive characteristic of Kilian's (2009) measure of global real activity is availability at a monthly frequency. This is the advantage over use of global GDP. However, the Kilian measure of global real activity represents global demand for commodities. Global GDP is a much broader measure of real activity. As an alternative specification of real activity we convert quarterly GDP for the largest four economies, the U.S., Eurozone, China and Japan into monthly GDP by interpolation of the quarterly data. Global GDP is not available on a quarterly basis, but that for the four largest economies is available at a quarterly frequency. ${ }^{13}$ For simplicity and to be consistence with our study we aggregate and interpolate the real GDP (deflated by U.S. PPI) measured in U.S. dollars of the U.S., Eurozone, China and Japan, to proxy for the global real GDP. These economies account for around $65 \%$ of global GDP in the period studied. We substitute the interpolated real GDP of the four largest economies for Kilian's measure of global real activity. In results not reported the impulse response on oil price of one standard deviation shocks to G3 M2 and China M2 (with GDP of the four largest economies measuring real activity) confirm our previous finding that shocks to China's

\footnotetext{
${ }^{13}$ Miller and Ni (2011) obtained annual global GDP data from Angus Maddison's historical statistics [Maddison (2010)] for 1971-2008 and used quarterly OECD GDP to interpolate global GDP at a quarterly frequency. The global GDP series only exist in annual frequency. However, the aggregation of the four largest economies can be obtained quarterly improving significantly the number of original observations in the interpolating procedure.
} 
M2 has statistically significant and persistent effects on real oil price, whereas shocks to M2 expansion in the U.S., Eurozone and Japan do not.

\section{Conclusion}

The movement in China's money supply drives the movement in world money supply over the last twenty years. Liquidity in China and in other major countries is introduced into the Kilian (2009) model identifying the supply and demand side factors driving real oil price changes. It is found that structural shocks are large for both G3 real M2 and China's real M2 over 1996:1-2011:12. However, the cumulative impact of real G3 M2 shocks on real oil prices is small in contrast to a large cumulative effect of China's real M2 on the real price of crude oil. Following unanticipated increases in China's real M2 growth there are significant increases in real oil prices that build up over six months and then persist. In contrast, innovations to U.S., Japanese or Eurozone real M2 do not significantly affect real oil price.

It is shown that increased liquidity in China relative to that in the U.S., Eurozone and Japan significantly raises real oil prices over 1996:1-2011:12. Following a sharp fall in real oil price in the last half of 2008, the cumulative impact of China's real M2 on the real price of crude oil is particularly substantial in the recovery of oil price during 2009 from a low of $\$ 41.68$ for January 2009. The analysis sheds light on the causes of movement in oil prices over the last twenty five years and in assessing the relative importance of China in the upsurge of the real price of crude oil.

\section{References}

Alquist, R., and L. Kilian (2010), "What Do We Learn from the Price of Crude Oil Futures?” Journal of Applied Econometrics, 25, 539-573.

Alquist, R., Kilian, L., and R.J. Vigfusson (2010), "Forecasting the Price of Oil," In G. Elliott and A. Timmermann (eds.), Handbook of Economic Forecasting, 2, Amsterdam: North-Holland. 
Arouri, M.E.H., Jouini, J., and Nguyen D.K. (2011), "Volatility spillovers between oil prices and stock sector returns: Implications for portfolio management," Journal of International Money and Finance 30(7), 1387-1405.

Barsky, R.B., and L. Kilian (2002), "Do We Really Know that Oil Caused the Great Stagflation? A Monetary Alternative," in: NBER Macroeconomics Annual 2001, B.S. Bernanke and K. Rogoff (eds.), MIT Press: Cambridge, MA, 137-183.

Belke, A., Bordon, I., and T. Hendricks (2010), "Global liquidity and commodity prices-a cointegrated VAR approach for OECD countries," Applied Financial Economics, 20(3), 227-242.

Bernanke B.S., Gertler, M., and M.W. Watson (1997), "Systematic Monetary Policy and the Effects of Oil Price Shocks," Brookings Papers on Economic Activity, 1, 91-142.

Bodenstein, M., Guerrieri, L., and L. Kilian (2012), "Monetary policy responses to oil price fluctuations," CEPR Discussion Papers 8928, C.E.P.R. Discussion Papers.

Fan, L., Yu, Y., and C. Zhang (2011), “An empirical evaluation of China's monetary policies,” Journal of Macroeconomics 33 (2), 358-371.

Frankel, J.A. (2008), “The Effect of Monetary Policy on Real Commodity Prices" in Asset Prices and Monetary Policy, J. Campell (ed.), University of Chicago Press.

Frankel, J.A., and A.K. Rose (2010), "Determinants of Agricultural and Mineral Commodity Prices," in: Fry, R., Jones, C., and C. Kent (eds), Inflation in an Era of Relative Price Shocks, Sydney, 9-51.

Gillman, M., and A. Nakov (2009), "Monetary Effects on Nominal Oil Prices," North American Journal of Economics and Finance, 20, 239-254.

Hamilton, J.D. (1983), "Oil and the Macroeconomy since World War II," Journal of Political Economy 91, 228-248.

Hamilton, J.D. (1994), Time Series Analysis, Princeton NJ, Princeton University Press.

Hamilton, J.D. (2009), “Causes and Consequences of the Oil Shock of 2007-08,” Brookings Papers on Economic Activity, 1, Spring, 215-261.

Hamilton, J.D. (2011), "Historical Oil Shocks," NBER Working Paper No. 16790. Forthcoming in The Routledge Handbook of Major Events in Economic History, Randall E. Parker (Author, Editor), Robert M. Whaples (Editor), Routledge, 2013.

Kilian, L. (2008a), "Exogenous Oil Supply Shocks: How Big Are They and How Much Do They Matter for the U.S. Economy?" Review of Economics and Statistics 90(2), 216-240.

Kilian, L. (2008b), "The Economic Effects of Energy Price Shocks," Journal of Economic Literature, 46, 871-909.

Kilian, L. (2009), "Not All Oil Price Shocks Are Alike: Disentangling Demand and Supply Shocks in the Crude Oil Market," American Economic Review, 99, 1053-1069. 
Kilian, L., and B. Hicks (2012), "Did Unexpectedly Strong Economic Growth Cause the Oil Price Shock of 2003-2008?" Journal of Forecasting, forthcoming.

Kilian, L., and L.T. Lewis (2011), "Does the Fed Respond to Oil Price Shocks?" The Economic Journal 121(555), 1047-1072

Kilian, L., and D.P. Murphy (2010), "The Role of Inventories and Speculative Trading in the Global Market for Crude Oil,” mimeo, University of Michigan.

Kilian, L., and R. J. Vigfusson (2011), “Are the Responses of the U.S. Economy Asymmetric in Energy Price Increases and Decreases?” Quantitative Economics 2(3), 419-453.

Maddison, Angus (2010) Statistics on World Population, GDP and Per Capita GDP, 1-2008 AD. GroningenGrowth and DevelopmentCentre, GroningenUniversity. http://www.ggdc.net/Maddison.

Miller, J.I., and S. Ni (2011), "Long-term Oil Price Forecasts: A New Perspective on Oil and the Macroeconomy,” Macroeconomic Dynamics 15 (S3), 396-415.

Park, J., and R. A. Ratti (2008), "Oil price shocks and stock markets in the U.S. and 13 European countries,” Energy Economics 30, 2578-2608.

Sadorsky, P. (2012), "Correlations and volatility spillovers between oil prices and the stock prices of clean energy and technology companies," Energy Economics 34 (1), 248-255.

Sims, C.A. (1980), “Macroeconomics and Reality”, Econometrica 48, 1-48. 
Figure 1a. Money supplies ( $\log$ M2) in China, U.S., Eurozone, Japan, U.K. and Switzerland: 1996:012011:12

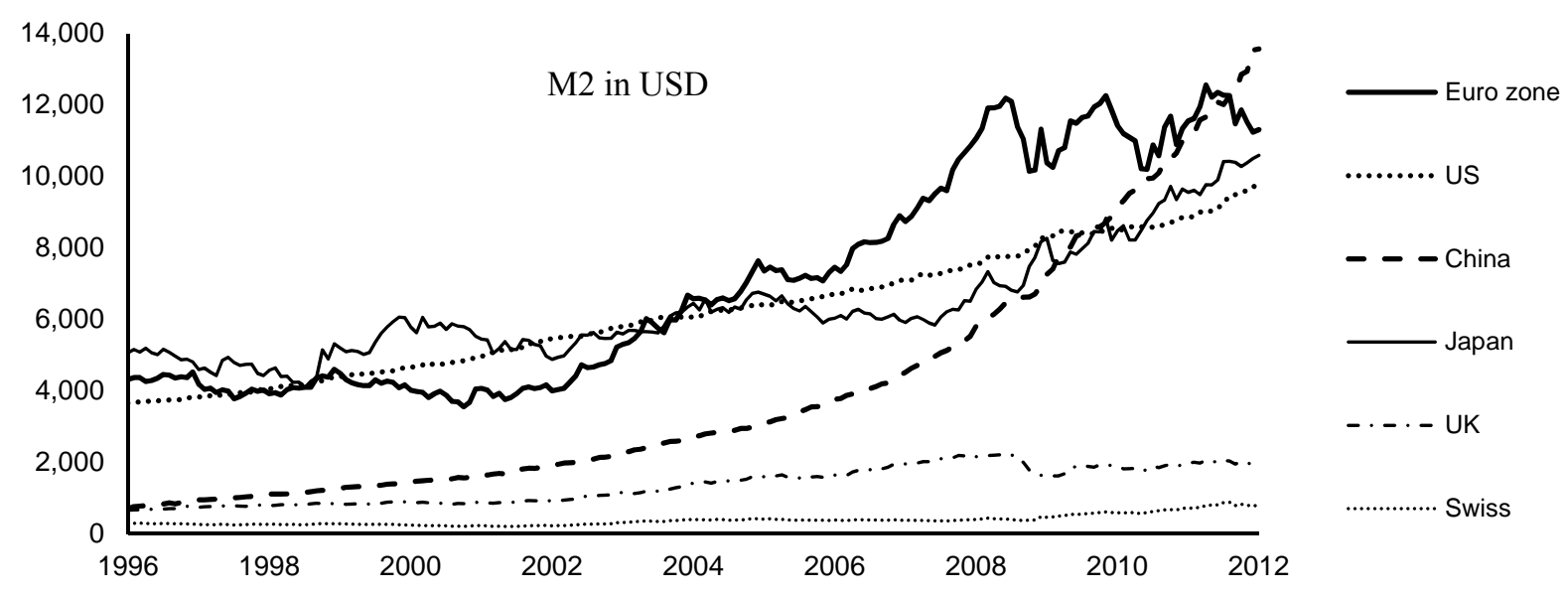

Figure 1b. Global (G3 plus China) money supply (logM2): 1996:01-2011:12

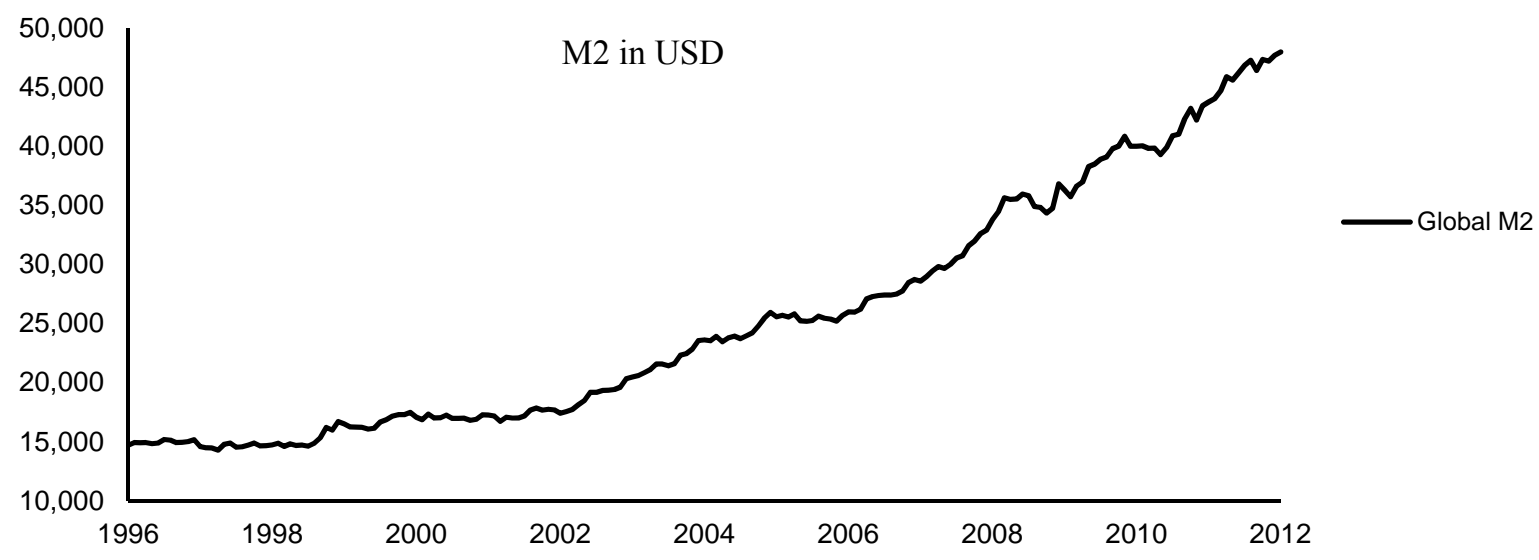

Figure 1c. China's nominal GDP (logGDP) and money supply (logM2): 1996:01-2011:12

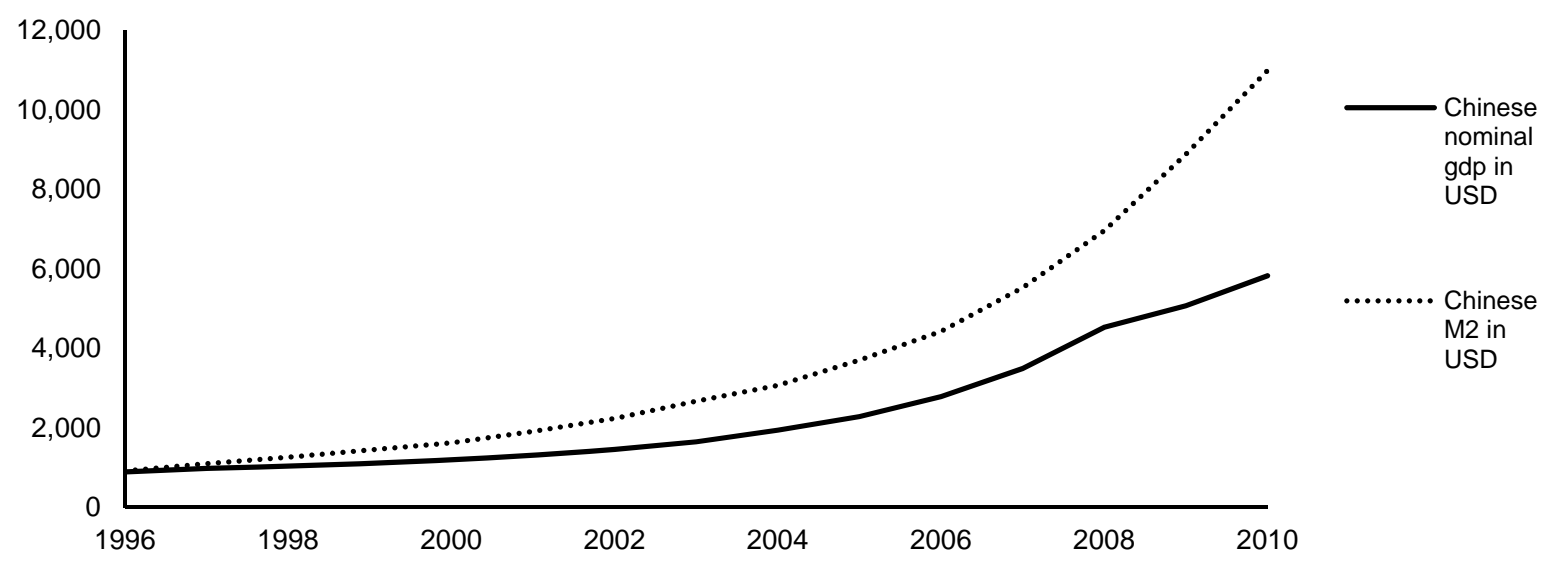


Figure 1d. Price of oil and G3 and China's money supplies (logM2): 1996:01-2011:12

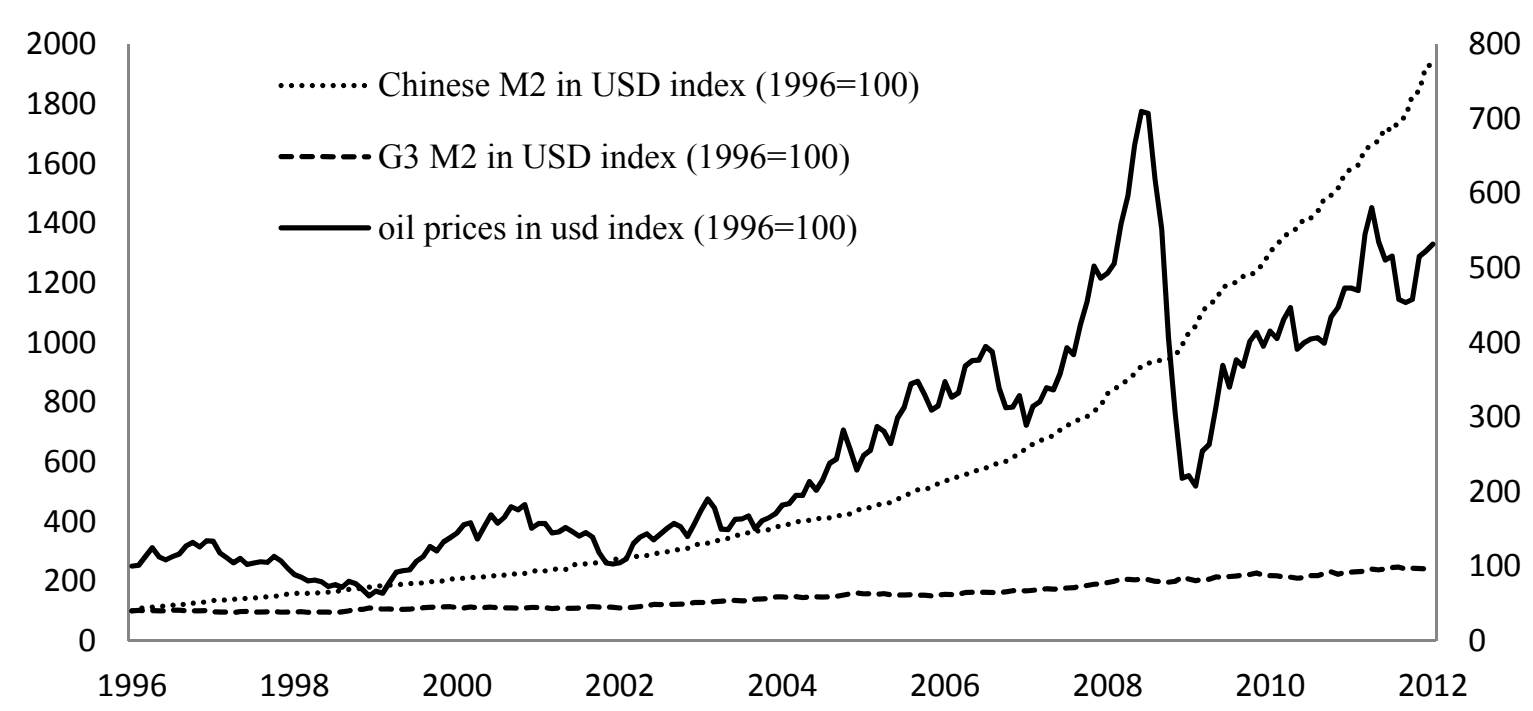

Figure 1e. G3 (U.S., Eurozone, Japan) and China Real M2: 1996:01-2011:12

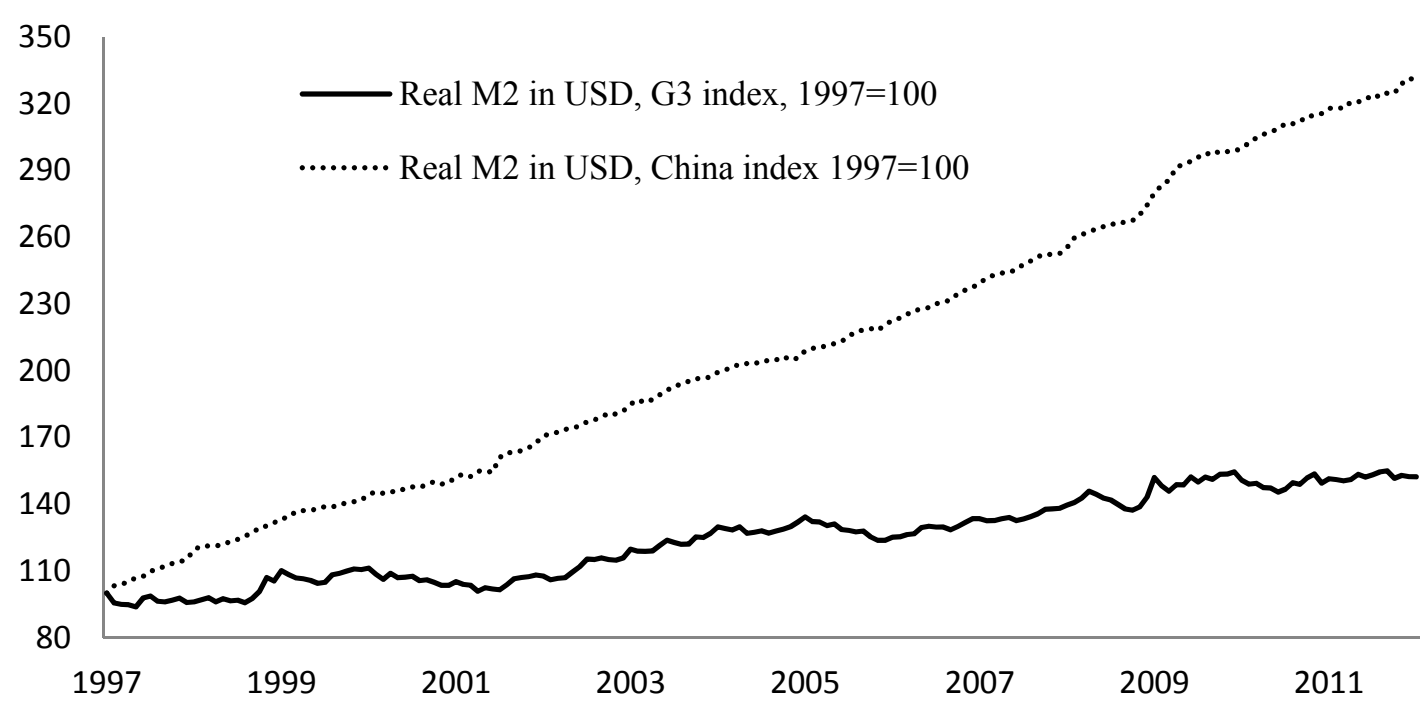

Notes: Global M2 is taken to be the sum of the M2 in China and in the G3. The G3 is taken to be the U.S., Eurozone and Japan. 
Figure 2. The Evolution of the Structural Shocks: 1996:01-2011:12
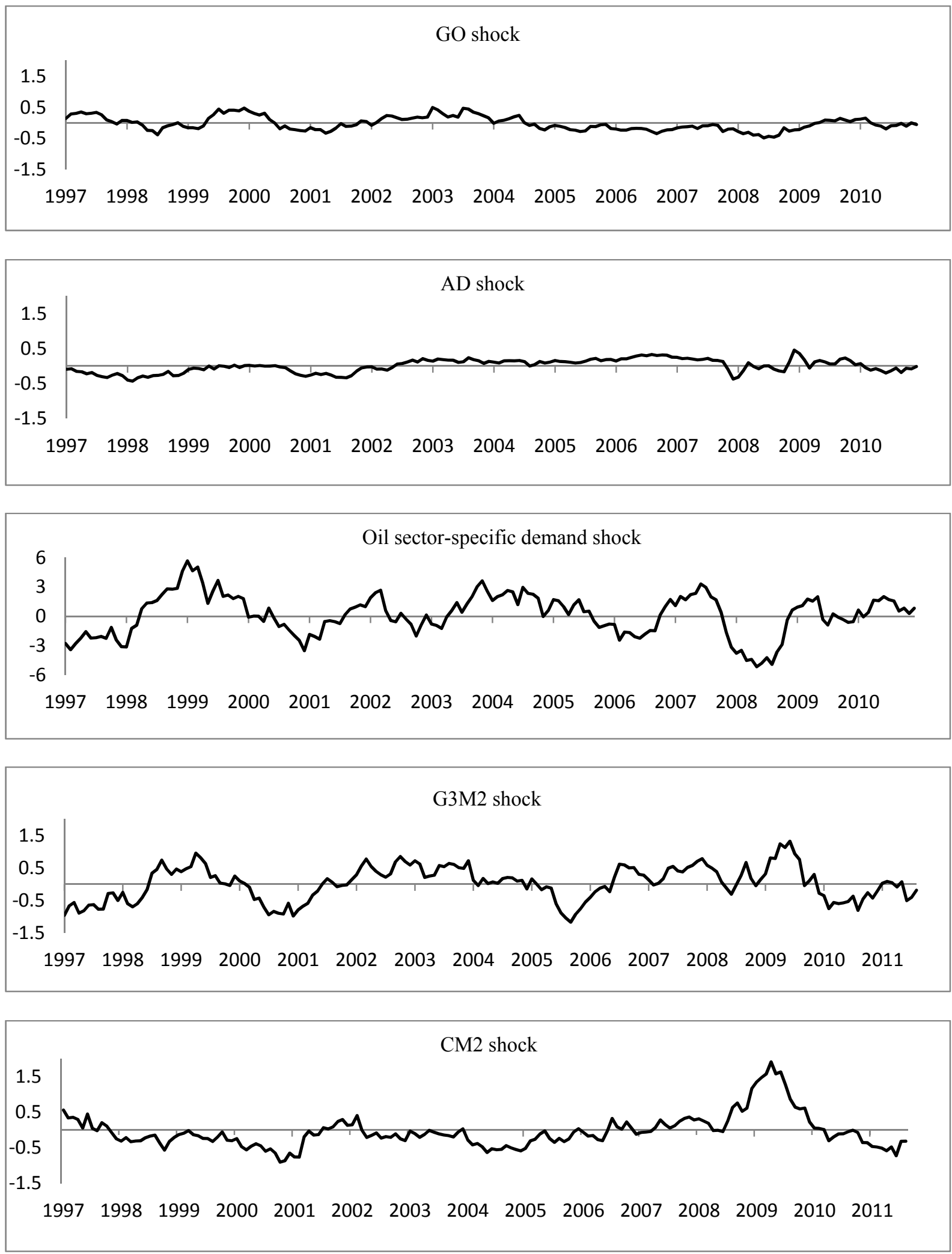

Notes: $G O$ is global oil production, $A D$ is aggregate demand shock, $R P$ is real oil price, $G 3 M 2$ is $\mathrm{M} 2$ of $\mathrm{G} 3$ countries, and CM2 is China's M2. 
Figure 3. The impulse response effects of the structural shocks: 1996:01-2011:12
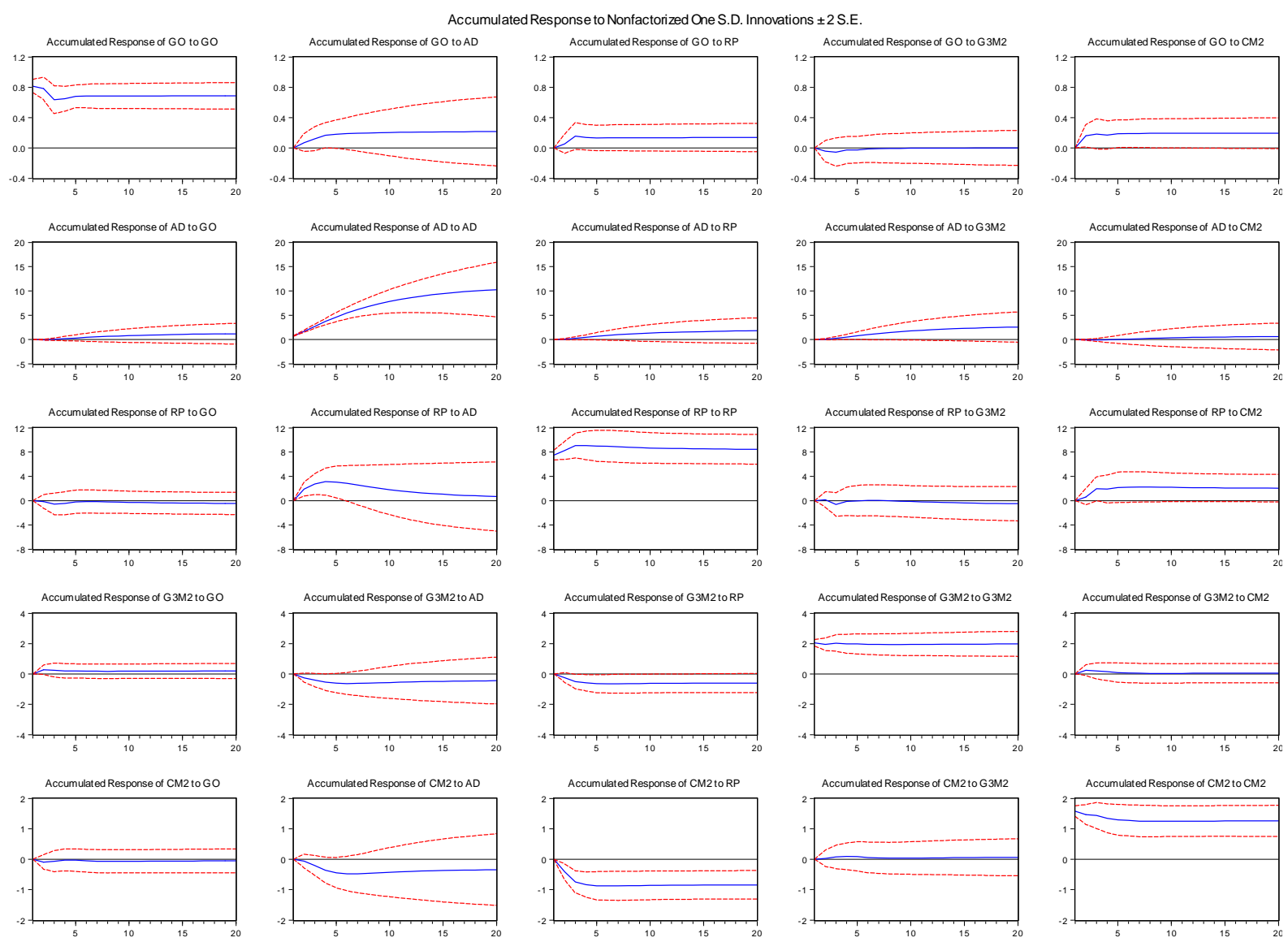

Notes: $G O$ is global oil production, $A D$ is aggregate demand shock, $R P$ is real oil price, $G 3 M 2$ is $M 2$ of $\mathrm{G} 3$ countries, and CM2 is China's M2. 
Figure 4. Cumulative effect of structural shocks on real price of oil (annual averages)
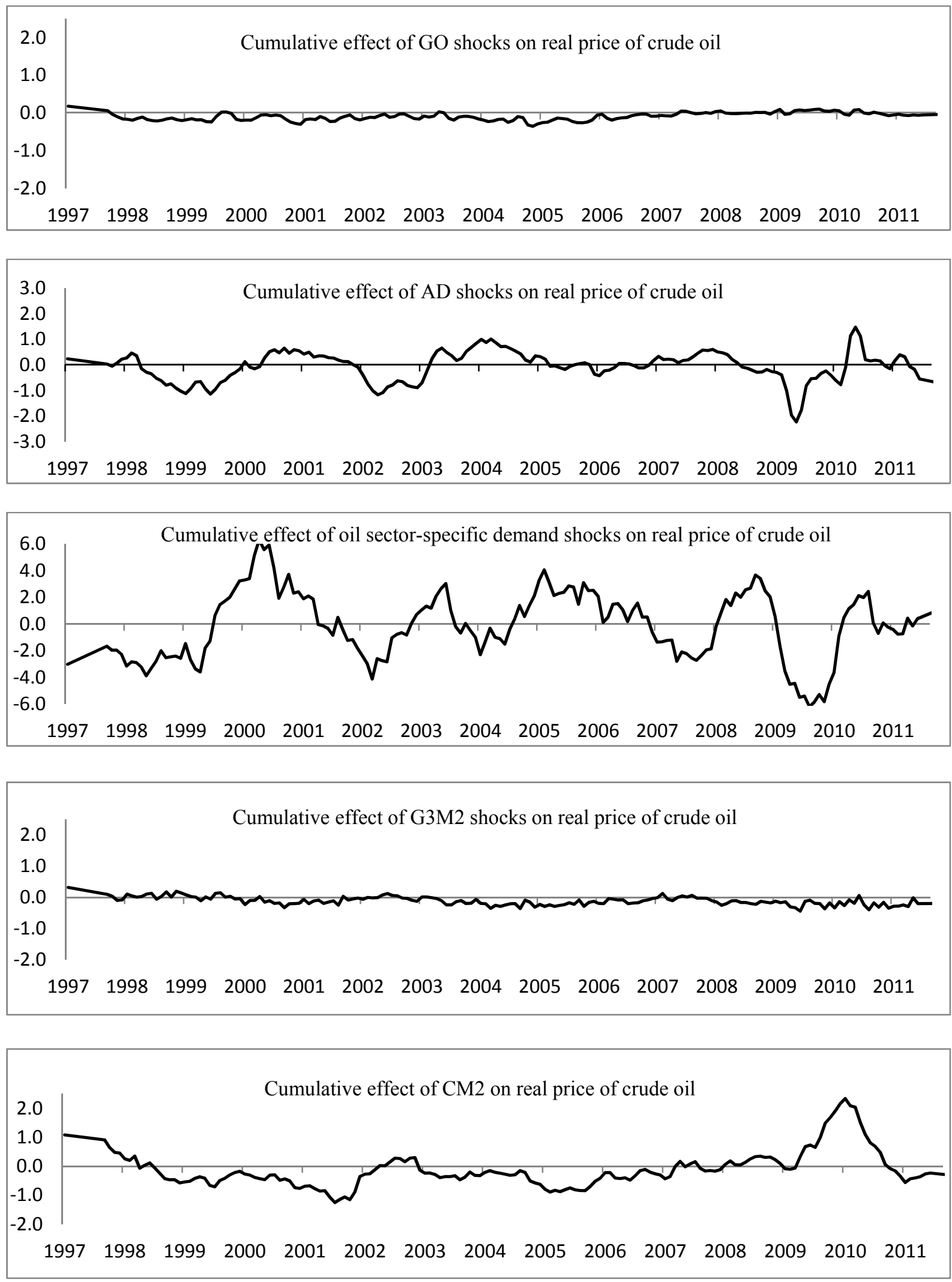

Notes: $G O$ is global oil production, $A D$ is aggregate demand shock, $R P$ is real oil price, $G 3 M 2$ is $M 2$ of $G 3$ countries, and CM2 is China's M2. 
Figure 5. The impulse response effects of the structural shocks: subsample 2004:02-2011:12
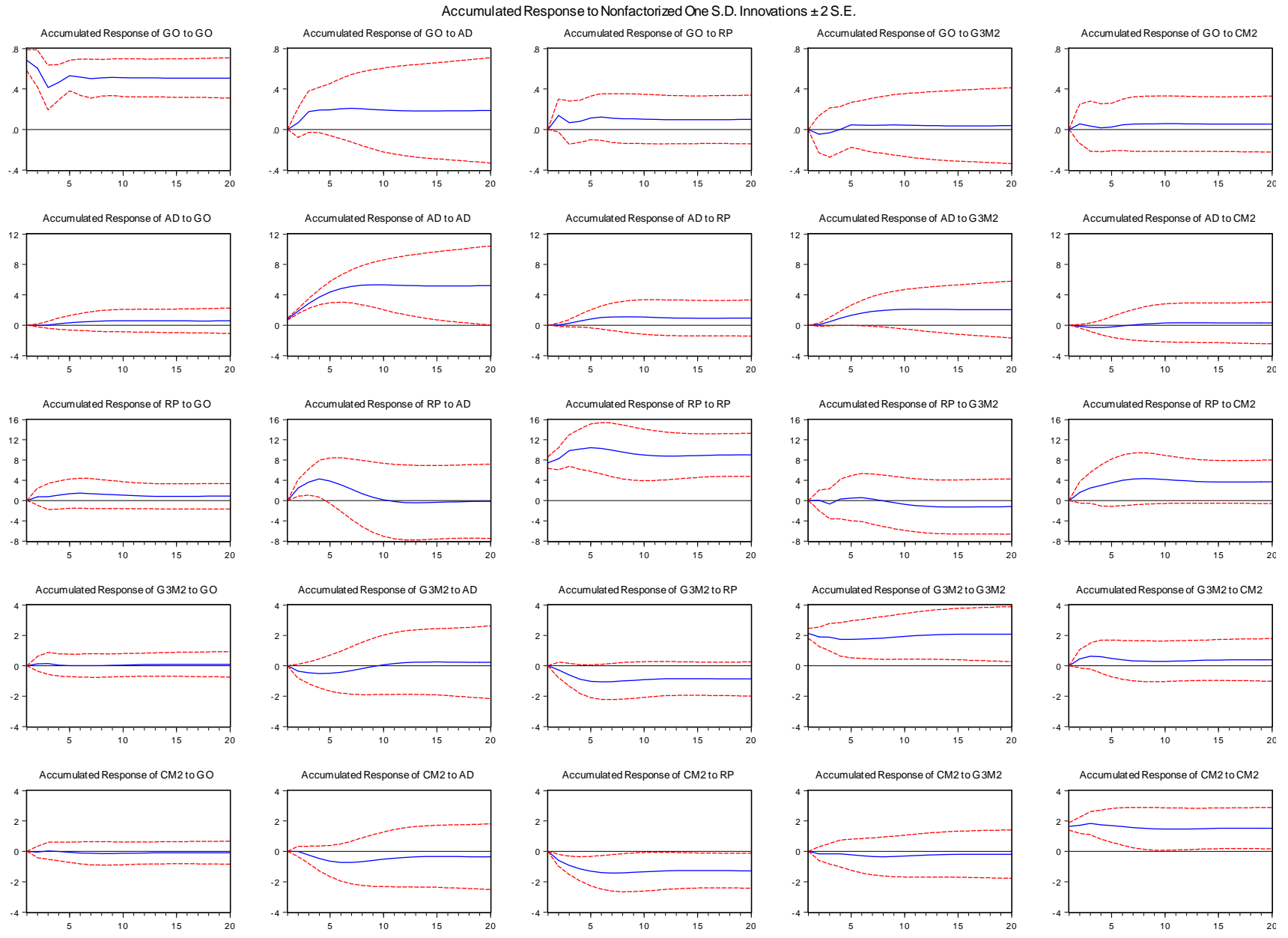

Notes: $G O$ is global oil production, $A D$ is aggregate demand shock, $R P$ is real oil price, G3M2 is M2 of G3 countries, and CM2 is China's M2. 
Figure 6. The impulse response effects of the structural shocks (U.S. CPI deflator):1996:01-2011:12
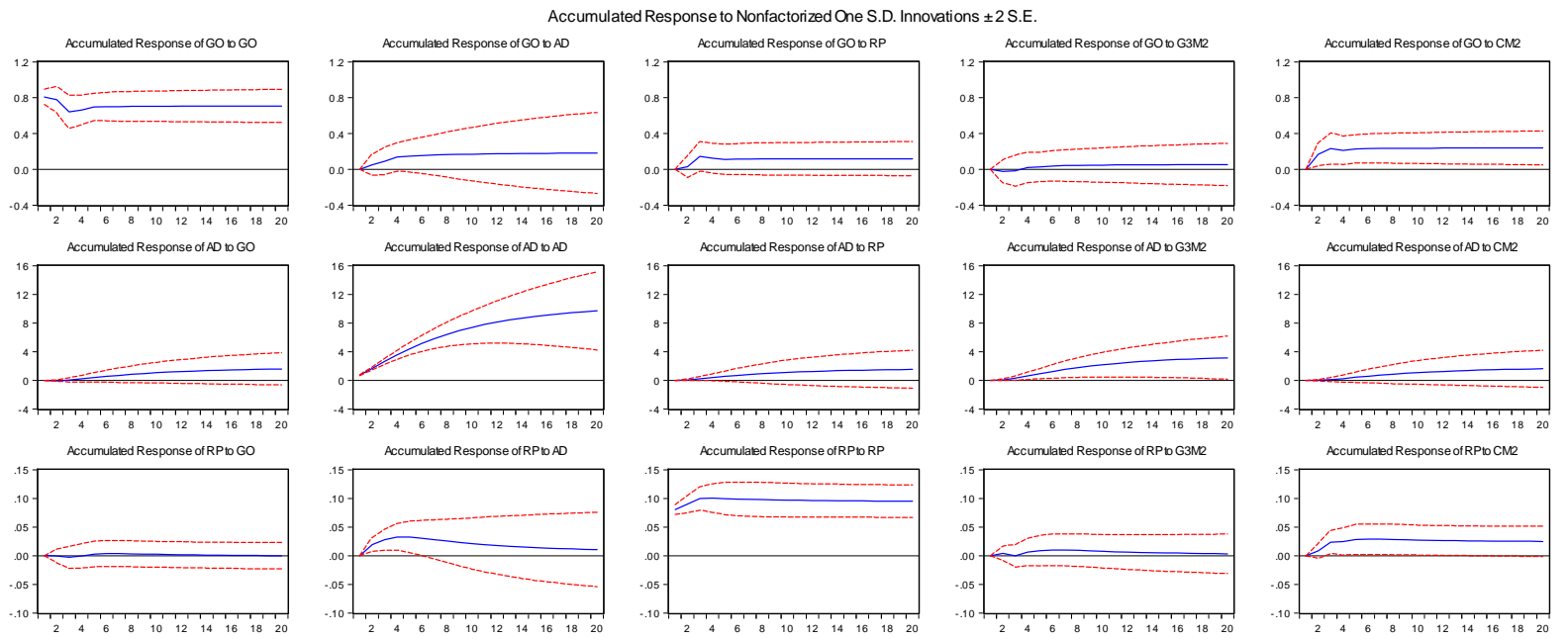

Accumulated Response of $G 3$ Ne $w$ GO

$$
\text { Accumulated Response of G3Ne } 1 \text { AD }
$$
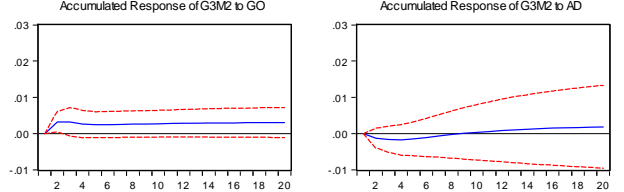

Accumulated Response of 332 mo

Accurulated Response
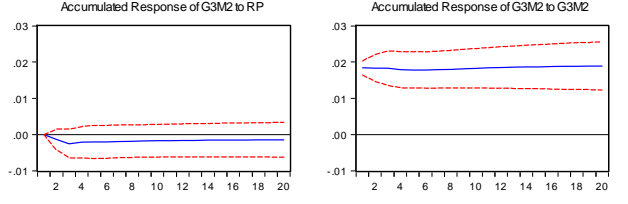

Accumulated Response of $33 \mathrm{M} 2$ to $\mathrm{C}$
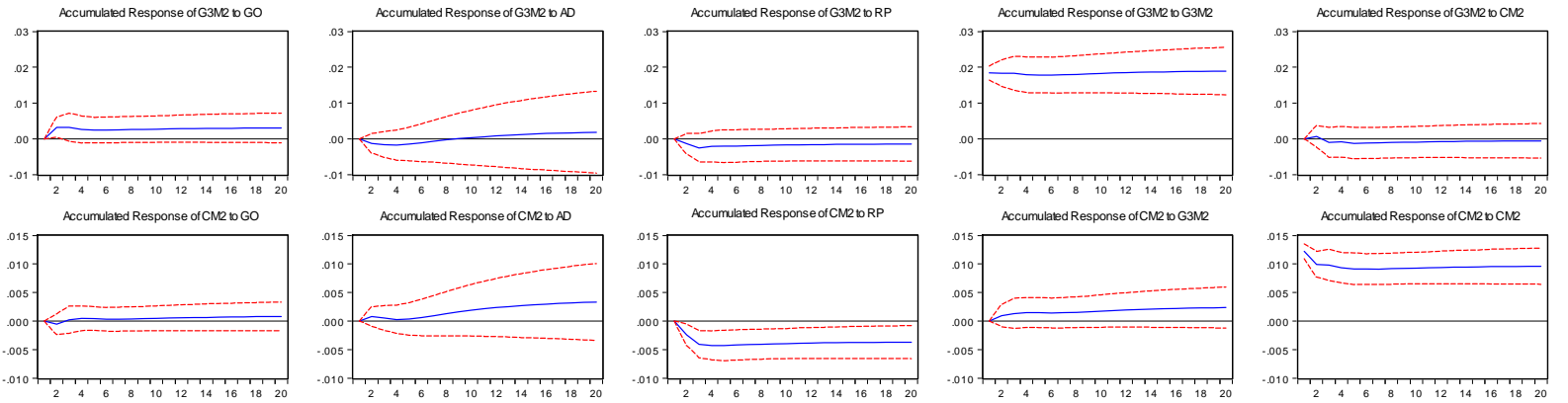

Notes: $G O$ is global oil production, $A D$ is aggregate demand shock, $R P$ is real oil price, G3M2 is M2 of G3 countries, and CM2 is China's M2. The nominal variables China's M2, the G3 M2 and oil prices are deflated by U.S. CPI. 


\section{School of Economics and Finance Discussion Papers}

2012-07 Identification-Robust Inference for Endogeneity Parameters in Linear Structural Models, Firmin Doko Tchatoka and Jean-Marie Dufour

2012-06 Specification Tests with Weak and Invalid Instruments, Firmin Doko Tchatoka

2012-05 Liquidity and Crude Oil Prices: China’s Influence Over 1996-2011, Ronald A. Rattia and Joaquin L. Vespignani

2012-04 On the Validity of Durbin-Wu-Hausman Tests for Assessing Partial Exogeneity Hypotheses with Possibly Weak Instruments, Firmin Doko Tchatoka

2012-03 Endogenous Crisis Dating and Contagion Using Smooth Transition Structural GARCH, Mardi Dungey, George Milunovich, Susan Thorp and Minxian Yang

2012-02 Testing for Partial Exogeneity with Weak Identification, Firmin Doko Tchatoka

2012-01 On the Correspondence Between Data Revision and Trend-Cycle Decomposition, Mardi Dungey, Jan PAM Jacobs and Jian Tian

2011-06 Systematic and Liquidity Risk in Subprime-Mortgage Backed Securities, Mardi Dungey, Gerald P. Dwyer and Thomas Flavin

2011-05 A SVECM Model of the UK Economy and The Term Premium, Mardi Dungey and M. Tugrul Vehbi

2011-04 Do Contact Matter in the Process of Getting a Job in Cameroon? Firmin Doko Tchatoka and Urbain Thierry Yogo

2011-03 Subset Hypotheses Testing and Instrument Exclusion in the Linear IV Regression, Firmin Doko Tchatoka

2011-02 First home Buyers’ Support Schemes in Australia - Results Spreadsheet, Mardi Dungey, Graeme Wells and Sam Thompson

2011-01 First home Buyers’ Support Schemes in Australia, Mardi Dungey, Graeme Wells and Sam Thompson

2010-12 Financial Crises in Asia: Concordance by Asset Market or Country?, Mardi Dungey, Jan P.A.M. Jacobs and Lestano

2010-11 Innovation Contracts with Leakage Through Licensing, Shane B. Evans

2010-10 Franchise Contracts with Ex Post Limited Liability, Shane B. Evans

2010-09 Menus of Linear Contracts in Procurement with Type-Dependent Reservation Utility, Shane B. Evans

2010-08 Decomposing the Price Effects on the Cost of Living for Australian Households, Paul Blacklow

2010-07 Modelling the Time Between Trades in the After-Hours Electronic Equity Futures Market, Mardi Dungey, Nagaratnam Jeyasreedharan and Tuo Li

2010-06 Cojumping: Evidence from the US Treasury Bond and Futures Markets, Mardi Dungey and Lyudmyla Hvozdyk

2010-05 Assessing the Impact of Worker Compensation Premiums on Employment in Tasmania, Paul Blacklow

2010-04 Non-Linear Pricing with Homogeneous Customers and Limited Unbundling, Hugh Sibly

2010-03 Detecting Contagion with Correlation: Volatility and Timing Matter, Mardi Dungey and Abdullah Yalama

2010-02

From Trade-to-Trade in US Treasuries, Mardi Dungey, Olan Henry and Michael McKenzie

2010-01

Economic Assessment of the Gunns Pulp Mill 2004-2008, Graeme Wells

Copies of the above mentioned papers and a list of previous years' papers are available from our home site at http://www.utas.edu.au/economics-finance/research/ 